DOI: 10.46340/eujem.2021.7.1.12

Vasyl Golian, ScD in Economics

ORCID ID: https://orcid.org/0000-0002-2502-4573

Public Organization "European Analytical Centre», Kyiv, Ukraine

Yurii Luchechko

ORCID ID: https://orcid.org/0000-0001-9006-5374

Lutsk National Technical University, Ukraine

Denys Shmarov

ORCID ID: https://orcid.org/0000-0003-3382-9408

Lutsk National Technical University, Ukraine

\title{
DETERMINANTS OF THE FORMATION \\ OF A SYSTEM FOR STIMULATING INVESTMENT ACTIVITY IN THE FOOD PROCESSING INDUSTRY SECTOR
}

\author{
Василь Голян, д.е.н. \\ Громадська організація «Європейський аналітичний чентр», м. Київ, Україна \\ Юрій Лучечко \\ Денис Шмаров
}

Луцький національний технічний університет, Україна

\section{ДЕТЕРМІНАНТИ ФОРМУВАННЯ СИСТЕМИ СТИМУЛЮВАННЯ ІНВЕСТИЦЙНОЇ ДІЯЛЬНОСТІ У СЕКТОРІ ПЕРЕРОБНО-ХАРЧОВИХ ВИРОБНИЦТВ}

It is established that the food processing sector acts as the basic link of the national agro-industrial complex, which provides processing of agricultural raw materials for the production of food products and industrial and energy goods and is an important component of the country's export potential. In the article, the main external (exogenous) and internal (endogenous) determinants are identified based on the use of axiomatic and abstract-logical methods. They must be taken into account when choosing tools for stimulating investment activity in the processing and food production sector in order to attract agricultural raw materials into economic circulation as effectively as possible and maximize the production of finished products with high added value. It is established that the group of endogenous determinants includes: 1 ) the formation of closed cycles in agricultural product chains; 2 ) an increase in the level of complexity of the use of agricultural raw materials and waste from agricultural production; 3) an increase in the level of capitalization of raw materials and processing segments of the agro-industrial production; 4) diversification of the development of processing units of the national agro-industrial complex; 5) activation of the sector of processing and food production in rural areas. It is revealed that the exogenous determinants that influence the choice of tools for stimulating investment activity in the processing segment of the national agro-industrial complex are the following: 1) aggravation of global problems of food supply of the population; 2) an increase in the share of energy that is produced from renewable sources; 3 ) activation of efforts of the world community in the fight against climate change; 4) entry into global agro-food chains of added value; 5) international transfer of modern technologies and management methods in the sector of processing and food production. It is established that the cumulative impact of endogenous and exogenous determinants on the investment process in the processing segment of the national agro-industrial complex requires institutionalization of fiscal, budgetary, price, credit and customs instruments.

Key words: investment activity, processing and food production, determinants, tools, incentives, waste. 
Постановка проблеми. У секторі переробно-харчових виробництв існують сприятливі передумови для введення додаткових потужностей за умови активізації інвестиційної діяльності як в частині модернізації, реконструкції та технічного переоснащення основного капіталу, так і в частині впровадження сучасних технологічних процесів переробки сільськогосподарської сировини. Активізація інвестиційної діяльності в переробному сегменті агропромислового виробництва потребує застосування зі сторони держави інструментів стимулювання. Враховуючи поглиблення процесів інтернаціоналізації та глобалізації світових ринків сільськогосподарської сировини та готових харчових продуктів при формуванні набору інструментів стимулювання інвестиційної діяльності у сфері переробки сільськогосподарської сировини необхідним $є$ врахування ендогенних та екзогенних детермінант.

Аналіз останніх досліджень і публікацій. У працях українських вчених обгрунтовується доцільність активізації інвестиційної діяльності усекторі переробно-харчових виробництв як необхідної передумови модернізації, реконструкції та технічного переоснащення основного капіталу та впровадження сучасних технологій і методів прийняття управлінських рішень.

А. Бритвєнко стверджує, що харчова промисловість - найбільш інвестиційно приваблива галузь української промисловості, що характеризується швидкою окупністю інвестицій, базою сировини для виробництва харчової продукції та існуванням ринків збутуㄹ․

Сфера переробки сільськогосподарської сировини охоплює комплекс видів виробничогосподарської діяльності в різних ланках національного АПК, що передбачає виробництво, переробку та реалізацію матеріально-речової субстанції рослинницької та тваринницької сировини, а також їх залучення у різні фази агропродуктового ланцюга. Тому структуроутворюючою ланкою сфери переробки сільськогосподарської сировини пропонується розглядати сектор переробно-харчових виробництв, складовою якого виступає харчова промисловість. Даний сектор відзначається продуктовою та виробничо-технічною диверсифікацією в різних регіонах країни і з однієї сторони передбачає наближеність до джерел сировини, а з іншої- до місць переробки та споживання. Потенційно сектор переробно-харчових виробництв $\epsilon$ базовою ланкою більшості регіонів України за умови нарощення обсягів інвестиційних вливань в модернізацію, реконструкцію та технічне переоснащення суб'єктів агропродовольчого підприємництва.

Залучення інвестицій у переробний сегмент АПК, як вважають О.Тарасова та М. Міхов, будучи складним i багатоаспектним народногосподарським завданням, охоплює цілий комплекс організаційно-правових та фінансово-економічних питань регулювання, спрямованих на формування діючих механізмів залучення інвестицій у харчову промисловість і пов'язаних 3 нею галузей². Харчова промисловість у зв'язку з своєю багатофункціональною спрямованістю відзначається широким спектром проблем, які необхідно враховувати при розробці регуляторного механізму стимулювання інвестиційної діяльності.

На необхідності створення умов для покращення інвестиційної привабливості переробнохарчового сегмента АПК акцентує увагу також В. Страшинський, який вважає, що зважаючи на економічні та політичні труднощі, які негативно впливають на агропромисловий сектор, більшої уваги потребує проблема залучення іноземних інвестицій та підвищення інвестиційної привабливості як країни в цілому, так і галузей харчової промисловості ${ }^{3}$. Найбільш поширеними проблемами для більшості підгалузей харчової промисловості виступають: високий рівень спрацювання основного та допоміжного виробничого устаткування; надмірна сировинна спрямованість; значна залежність від цінових коливань на глобальному ринку продовольства; незадовільний рівень споживання продукції харчової промисловості в середині країни. Врахування цих проблем має виступати відправною точкою у виборі методів, форм та джерел інвестиційного забезпечення переробки сільськогосподарської сировини.

Високим рівнем комплексності відзначається розуміння базових детермінант інвестування О. Непочатенко, згідно якого необхідно більше уваги приділяти стратегії реального інвестування для можливості технічного переоснащення аграрної галузі в цілому ${ }^{4}$.

\footnotetext{
${ }^{1}$ Бритвєнко, А. С. (2015). Інвестиційна політика підприємств у сфері харчової промисловості. Вісник Бердянського університету менеджменту та бізнесу, 1 (29), 27-29.

${ }^{2}$ Тарасова, О. В., Міхов, М. М. (2011). Проблеми поліпшення інвестиційного клімату в харчовій промисловості України. Економіка харчової промисловості, 4, 33-36.

${ }^{3}$ Страшинський, В. І. (2015). Інвестиційне забезпечення підприємств харчової промисловості: стан, тенденції та проблеми. Науковий часопис НПУ імені М. П. Драгоманова, 28, 65-72.

${ }^{4}$ Непочатенко, О. О. (2014). Активізація інвестиційної діяльності як спосіб зміцнення фінансової безпеки аграрного сектору. Агросвіт, 2, 3-6.
} 
Конкурентною перевагою сектору переробно-харчових виробництв $\epsilon$ достатність та наближеність переважної більшості видів сільськогосподарської сировини, що при умові вчасного поповнення оборотних коштів та оновлення парку виробничого устаткування дасть можливість на порядок підвищити рівень капіталізації національного АПК в цілому, а також дасть поштовх розвитку суміжних ланок господарського комплексу.

На думку О. Бахматюка, інвестиційна інфраструктура виступає необхідною передумовою форсування інвестиційного процесу у всіх фазах агропродуктового ланцюга і тому має отримати необхідний регуляторний вплив держави, щоб охоплювати критично необхідну для повноцінного інвестиційного процесу сукупність інститутів інвестиційної діяльності ${ }^{1}$.

Комплексне вирішення проблеми нарощення потужностей по переробці сільськогосподарської сировини, на думку Д. Крисанова та О. Варченко, потребує значного обсягу капітальних вкладень, фінансування яких стане можливим за умови диверсифікації джерел, методів та способів залучення фінансових ресурсів ${ }^{2}$.

Водночас при формуванні комплексу інструментів стимулювання інвестиційної діяльності у секторі переробно-харчових виробництв необхідно враховувати зовнішній вплив та внутрішньогалузеві проблеми поповнення фондів інвестиційного забезпечення модернізації та реконструкції основного капіталу підприємств переробного сегмента АПК.

Цілі статті. Метою даної статті $є$ визначення основних детермінант, які впливають на формування системи інструментів стимулювання інвестиційної діяльності в секторі переробнохарчових виробництв.

Виклад основного матеріалу дослідження. Базова конструкція сектору переробно-харчових виробництв України ще сформувалася в умовах командно-адміністративної економіки і була зорієнтована в першу чергу на задоволення споживчих потреб місцевого населення. Наявність значної кількості великотоварних сільськогосподарських підприємств створювала надійну та прогнозовану сировинну базу для підприємств харчової промисловості, що в підсумку робило переробно-харчові підприємства центрами комплексоутворення окремих адміністративних районів та населених пунктів. Такі переробно-харчові підприємства випускали якісну продукцію, яка задовольняла потреби жителів окремих адміністративно-територіальних одиниць і спрямовувалася в інші регіони, особливо на найбільш урбанізовані території. Однак, глибока трансформаційна та стагнаційна криза на початку 90-х років минулого століття призвела до деструктивних структурних зрушень у харчовій промисловості.

У значній кількості адміністративних районів підприємства по виробництву харчових продуктів були демонтовані, що в результаті призвело до значних перегинів в регіональних агропродуктових ланцюгах. Це у свою чергу також вплинуло на структуру регіонального та місцевого господарства, а також звузило попит на продукцію сільськогосподарських підприємств. Лише на початку 2000-х років, коли у харчовій промисловості відбулось формування критичного набору ринкових інститутів та була забезпечена прийнятна концентрація інвестиційних ресурсів розпочалось формування сучасних агропродуктових ланцюгів і почали формуватися харчові підприємства на новій технологічній, техніко-експлуатаційній та логістично-складській основі. Формуванню такого роду підприємств сприяло також загострення глобальних проблем забезпечення продовольством, що сформувало попит на продукцію українських виробників харчових продуктів.

Певний деструктивний вплив на динаміку розвитку харчової промисловості справили торгові війни з окремими країнами СНД, що призвело до втрати роками сформованих ніш на ринках цих країн. Підписання Угоди між Україною та Європейським Союзом щодо зони вільної торгівлі у короткостроковій перспективі не дало значного поштовху розвитку вітчизняних підприємств харчової промисловості у зв'язку з наявністю в країнах Європейського Союзу жорстких тарифних та нетарифних обмежень. Сповільнюючим чинником розширеного відтворення ресурсно-виробничого потенціалу підприємств харчової промисловості виступає мляве впровадження упрактику виробничо-господарської діяльності вітчизняних товаровиробників регламентів та стандартів безпечності та якості продовольчої продукції, які функціонують в рамках ЄС.

\footnotetext{
${ }^{1}$ Бахматюк, О. Р. (2013). Інфраструктурні складові інвестиційного розвитку аграрного регіону. Агросвіт, 23, 16-21.

${ }^{2}$ Крисанов, Д. Ф., Варченко, О. М. (2017). Агропродовольчі ланцюги: ключові проблеми створення та розбудови. Економіка і прогнозування, 1, 72-91.
} 
Основними складовими харчової промисловості, базова структура котрої сформувалася в умовах командно-адміністративної економіки, є наступні: м'ясна та м'ясопереробна, молочна та молокопереробна, цукрова, борошномельно-круп'яна, хлібопекарна, кондитерська, олійно-жирова, рибна, плодоовочева, крохмале-патокова, консервна, спиртова, виноробна, пиво-безалкогольна та інші. У перехідний період та в умовах ринку найбільш інтенсивно розвивалися ті складові харчової промисловості, які були зорієнтовані на постачання на зовнішній ринок харчових продуктів, відходів та залишків харчової промисловості, харчових напівфабрикатів, які у високорозвинених країнах використовуються не лише як фактор продовольчої безпеки, але і як сировина для виробництва продуктів виробничо-технічного та енергетичного призначення.

Іншою вагомою складовою сектору переробно-харчових виробництв виступає переробка сільськогосподарської сировини з метою виробництва продукції виробничо-технічного призначення, яка передбачає виготовлення продуктів для потреб промислового виробництва та енергетичних потреб. Тобто ця складова сектору переробно-харчових виробництв забезпечує переробку сільськогосподарської сировини у готові продукти, які використовуються у промисловому виробництві, зокрема у текстильній промисловості, а також для покращення енергетичного балансу країни та експорту енергоресурсів за межі країни. У сегменті переробки сільськогосподарської сировини для потреб промислового виробництва виокремлюють: виробництво напівфабрикатів, виробництво складових матеріально-технічної субстанції готової продукції, виробництво допоміжних та пакувальних матеріалів. У сегменті переробки сільськогосподарської сировини з метою задоволення енергетичних потреб виділяють: виробництво біодизелю, виробництво біоетанолу, виробництво твердого біопалива та виробництво біогазу.

Схвалення нових енергетичних індикаторів в Свропейському Союзі спровокувало посилення енергетичної спрямованості сільськогосподарського виробництва, що у свою чергу сформувало потенційно привабливий сегмент в секторі переробно-харчових виробництв, який зорієнтований на виробництво енергетичних продуктів з відновних джерел. Суперечливим моментом такого структурного зрушення $є$ те, що українські виробники виступають сировинними придатками глобальної індустрії виробництва продуктів із відновних джерел енергії. Оптимальним варіантом у даній ситуації стала б розбудова вітчизняної індустрії поглибленої переробки сільськогосподарської сировини з метою задоволення енергетичних потреб. Мова йде про переробку сільськогосподарської продукції для виробництва біодизелю, біоетанолу, твердого біопалива та біогазу. В іншому разі, якщо збережеться нинішній тренд заготівлі та первинної переробки сільськогосподарської сировини енергетичного спрямування, сільськогосподарське виробництво України буде ще більш зорієнтоване на енергетичні цілі, що несе прямі загрози продовольчій безпеці країни.

Важливим сегментом сектору переробно-харчових виробництв в Україні з огляду на значні обсяги сільськогосподарської сировини, яка переробляється, виступає переробка відходів сільськогосподарського виробництва та харчових продуктів. В останні роки у структурі сукупного аграрного експорту питома вага відходів та залишків харчової промисловості становить більше $40 \%$, що посилює сировинну спрямованість національного АПК та поглиблює процеси вивезення за межі країни доданої вартості, яка за умови створення відповідних виробничо-технічних умов мала би створюватися в середині країни. Фактично сьогодні відходи олійно-жирової та борошномельнокруп'яної, а також цукрової промисловості вивозяться за кордон, що нарощує сировинний сегмент у секторі переробно-харчових виробництв.

Така ситуація у вітчизняному секторі переробно-харчових виробництв вимагає активізації інвестиційної діяльності, що стане можливим за наявності відповідної системи стимулювання, яка охоплюватиме комплекс методів та інструментів, що спонукатимуть суб'єктів сфери переробки сільськогосподарської сировини нарощувати інвестиційні потоки у модернізацію та реконструкцію основного капіталу. Водночас підбір методів та інструментів стимулювання має враховувати комплекс зовнішніх (екзогенних) та внутрішніх (ендогенних) детермінант.

Структурні зрушення у вітчизняному секторі переробно-харчових виробництв та інтернаціоналізація і глобалізація агропропродуктових ланцюгів дають підстави зробити припущення про вирішальний вплив на вибір методів та інструментів стимулювання інвестиційної діяльності у переробному сегменті національного АПК ендогенних та екзогенних детермінант (Результати ідентифікаиї екзогенних та ендогенних детермінант стимулювання інвестиційної діяльності у секторі переробно-харчових виробнищтв приведені на Рисунку 1). 


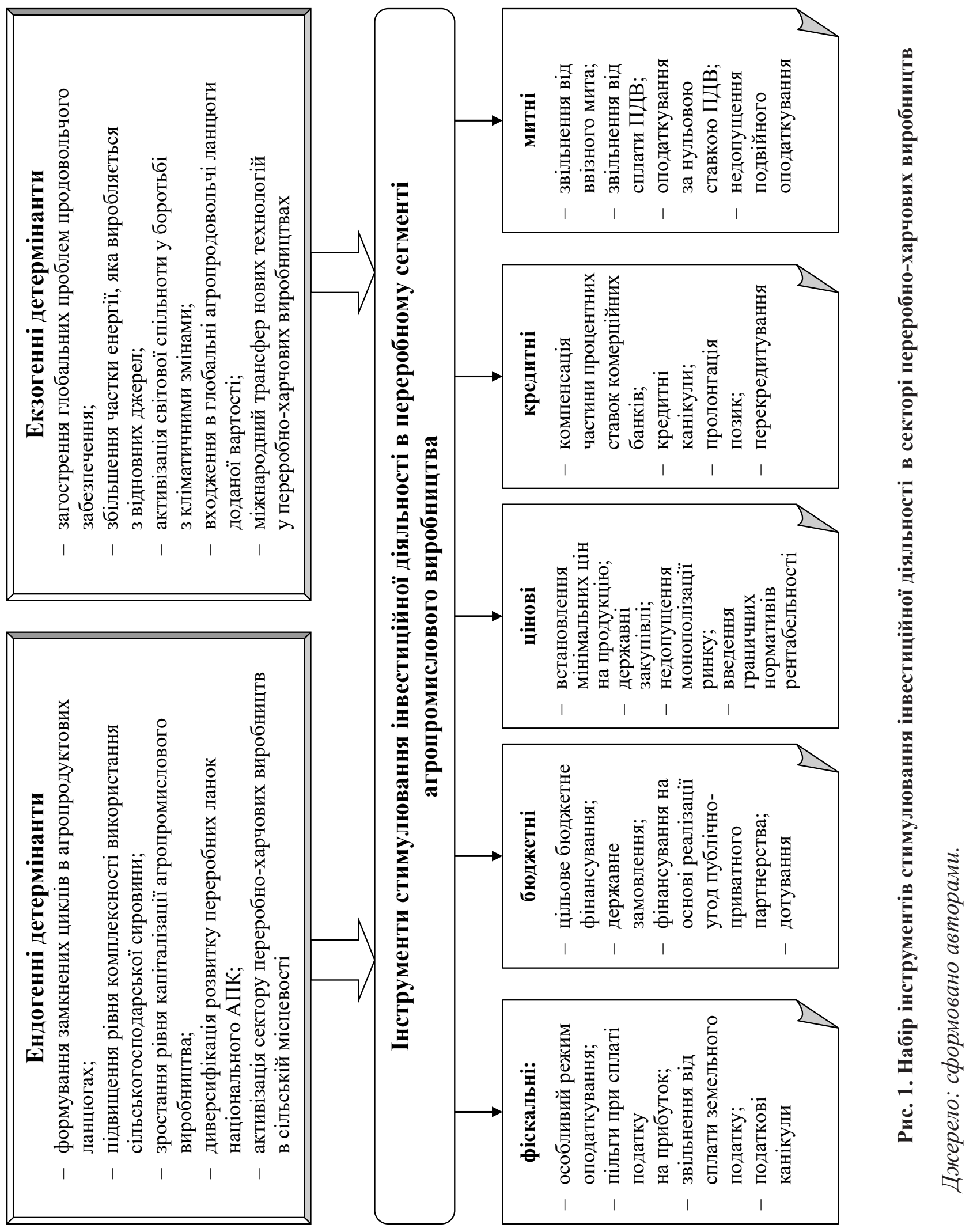


При врахуванні ендогенних детермінант необхідно виходити з того, що в середині країни варто забезпечувати максимальну замкненість циклів в агропродуктових ланцюгах, щоб зменшити вихід кінцевої продукції з низькою доданою вартістю і збільшити випуск готових харчових продуктів. Саме незначна кількість замкнених циклів в агропродуктових ланцюгах більшості регіонів України призводить до нарощення сировинних експортних потоків в національному АПК. У спектрі ендогенних детермінант важливо також враховувати необхідність підвищення рівня комплексності використання сільськогосподарської сировини, щоб максимальною мірою зменшувати непродуктивні втрати матеріально-речової субстанції продукції сільського господарства i забезпечувати результативну утилізацію відходів та залишків харчової промисловості. Це з однієї сторони дасть можливість використати ще один резерв підвищення ефективності використання сільськогосподарської сировини, а з іншої - забезпечити комплексність її використання.

Однією з основних ендогенних детермінант розроблення інструментарію стимулювання інвестиційної діяльності в переробному сегменті агропромислового виробництва $є$ забезпечення зростання рівня капіталізації агропромислового виробництва, що створить умови для нарощення внутрішніх джерел інвестиційного забезпечення розширеного відтворення основного капіталу переробно-харчових виробництв і в кінцевому підсумку дасть можливість перевести даний сектор сфери переробки сільськогосподарської сировини на принципово інший техніко-технологічний рівень. Враховуючи значні обсяги сільськогосподарської сировини, яка виробляється в Україні і ії видову різноманітність, вагомою ендогенною детермінантою активізації інвестиційного процесу в переробній ланці АПК виступає забезпечення диверсифікації розвитку переробних ланок, зорієнтованої на урізноманітнення номенклатури та асортименту готової продукції, виходячи із споживчих уподобань та потреб суміжних галузей як у глобальному, так і в національному масштабі.

Визначаючи пріоритети стимулювання інвестиційної діяльності в переробному сегменті агропромислового виробництва, необхідно виходити з того, що розширене відтворення потенціалу переробно-харчових виробництв $\epsilon$ за нинішніх умов однією 3 найважливіших передумов територіального комплексоутворення у сільській місцевості. Це пов'язано з тим, що у сільській місцевості формуються основні сировинні потоки і має місце значна кількість вільної робочої сили, що робить сектор переробно-харчових виробництв найбільш пріоритетною ланкою сільського розвитку у найближчій перспективі.

Критично необхідною екзогенною детермінантою, яку необхідно враховувати при виборі інструментів стимулювання інвестиційної діяльності в секторі переробно-харчових виробництв, $\epsilon$ врахування базових умов загострення глобальних проблем продовольчого забезпечення. На основі забезпечення належної ідентифікації глобальних проблем продовольчого забезпечення необхідно проектувати інвестиційні потоки у секторі переробно-харчових виробництв, що врешті-решт забезпечує структурні зрушення у всіх сегментах даного сектору. Тобто врахування глобальних проблем продовольчого забезпечення дасть можливість сформувати інституціональні передумови для фінансування модернізації та реконструкції регіональних агропромислових комплексів в сторону розширеного відтворення тих виробництв, які зорієнтовані на експорт готових харчових продуктів, а не на вивіз за межі країни сільськогосподарської сировини та залишків і відходів харчової промисловості.

Виходячи з того, що Україна в останні роки стала територіальним базисом виробництва сільськогосподарської сировини, яка використовується для виробництва енергії за кордоном, при виборі пріоритетних інструментів стимулювання інвестиційної діяльності в переробному сегменті агропромислового виробництва слід враховувати основні тренди розвитку світового ринку відновних джерел енергії. Це потрібно для того, щоб Україна поступово перетворювалася з глобального постачальника сільськогосподарської сировини енергетичного спрямування на глобального гравця, який здійснює виробництво енергії з відновних джерел. Це стане можливим за умови модернізації та реконструкції сегменту переробно-харчових виробництв, зорієнтованого на переробку сільськогосподарської сировини енергетичного спрямування та виробництво біодизелю, біоетанолу, біогазу та твердого біопалива в середині країни.

В нинішніх умовах, коли в підтримці проектів виробництва енергії з відновних джерел має місце перегин в сторону вітроенергетики через застосування гіпертрофовано високого зеленого тарифу, перспективи налагодження виробництва перерахованих вище видів енергії з відновних джерел $€$ нереалістичними. Вагомою екзогенною детермінантою активізації інвестиційної діяльності 
в секторі переробно-харчових виробництв виступає врахування базових умов формування глобальної конструкції боротьби з кліматичними змінами, що створить передумови для залучення додаткових інвестиційних ресурсів в рамках реалізації проектів боротьби з кліматичними змінами та стимулюватиме розвиток тих видів сільськогосподарського виробництва, які не забезпечують суттєвого збільшення викидів парникових газів.

Однією з основних екзогенних детермінант, що може вирішальною мірою вплинути на динаміку інвестування сектору переробно-харчових виробництв в Україні, $\epsilon$ входження вітчизняних товаровиробників в глобальні агропродовольчі ланцюги доданої вартості. Це фактично означає зміцнення позицій українських виробників сільськогосподарської та харчової продукції на світових ринках продуктів з високою доданою вартістю. Сьогодні Україна повною мірою не використовує свій наявний ресурсно-виробничий потенціал для збільшення власної ніші на глобальному ринку готових харчових продуктів. Вагомою передумовою підвищення технікотехнологічного рівня вітчизняних переробно-харчових виробництв i відповідно конкурентоспроможності готової продукції є швидке реагування на глобальні тренди впровадження нових технологій у переробно-харчових виробництвах. Досвід показує, що основними виробниками нових технологій виступають провідні транснаціональні корпорації, які функціонують на глобальному ринку продовольства.

Виходячи із приведених екзогенних та ендогенних детермінант $\mathrm{i}$ критичного аналізу напрацювань вітчизняних вчених основними групами інструментів стимулювання інвестиційної діяльності у секторі переробно-харчових виробництв виступають: фіскальні, бюджетні, цінові, кредитні та митні. До фіскальних інструментів відносяться: особливий режим справляння ПДВ, пільги при сплаті податку на прибуток, звільнення від сплати земельного податку, податкові канікули. Бюджетні інструменти охоплюють: цільове бюджетне фінансування, державне замовлення, фінансування на основі реалізації угод публічно-приватного партнерства, дотування. Ціновими інструментами стимулювання інвестиційної діяльності у переробно-харчовому сегменті виступають: встановлення мінімальних цін на продукцію, державні закупівлі, недопущення монополізації ринку, введення граничних нормативів рентабельності. Кредитні інструменти охоплюють: компенсація частини процентних ставок комерційних банків, кредитні канікули, пролонгація позик, перекредитування. Митне стимулювання включає такі інструменти: звільнення від ввізного мита, звільнення від сплати ПДВ, оподаткування за нульовою ставкою ПДВ, уникнення подвійного оподаткування.

Висновки $з$ дослідження. Дослідження показали, що при формуванні набору інструментів стимулювання інвестиційної діяльності у секторі переробно-харчових виробництв необхідно враховувати комплекс екзогенних та ендогенних детермінант формування агропродуктових ланцюгів, щоб максимальною мірою використати резерви підвищення ефективності використання сільськогосподарської сировини і утилізації харчових відходів і відходів сільськогосподарського виробництва. Основними ендогенними детермінантами, які необхідно враховувати при формуванні інструментарію стимулювання інвестиційної діяльності в переробному сегменті агропромислового виробництва, виступають: формування замкнених циклів в агропродуктових ланцюгах, підвищення рівня комплексності використання сільськогосподарської сировини, зростання рівня капіталізації агропромислового виробництва, диверсифікація розвитку переробних ланок національного АПК, активізація сектору переробно-харчових виробництв в сільській місцевості як важливої передумови територіального комплексоутворення. Основними екзогенними детермінантами стимулювання інвестиційних процесів у секторі переробно-харчових виробництв $є$ : загострення глобальних проблем продовольчого забезпечення, збільшення частки енергії, яка виробляється з відновних джерел, боротьба з кліматичними змінами, входження в агропродовольчі ланцюги доданої вартості, впровадження нових технологій у переробно-харчових виробництвах. Означені детермінанти вимагають застосування податкових, бюджетних, цінових, кредитних та митних інструментів стимулювання інвестиційних процесів у різноманітних фазах агропродуктових ланцюгів.

\section{References:}

1. Brytvienko, A. S. (2015). Investytsiina polityka pidpryiemstv u sferi kharchovoi promyslovosti [Investment policy of enterprises in the food industry]. Visnyk Berdianskoho universytetu menedzhmentu ta biznesu [Bulletin of Berdiansk University of Management and Business], 1 (29), 27-29. [in Ukrainian].

2. Tarasova, O. V., Mikhov, M. M. (2011). Problemy polipshennia investytsiinoho klimatu v kharchovii promyslovosti Ukrainy [Problems of improving the investment climate in the food industry of Ukraine]. Ekonomika kharchovoi promyslovosti [Economics of food industry], 4, 33-36. [in Ukrainian]. 
3. Strashynskyi, V. I. (2015) Investytsiine zabezpechennia pidpryiemstv kharchovoi promyslovosti: stan, tendentsii ta problemy [Investment support of food industry enterprises: state, tendencies and problems]. Naukovyi chasopys NPU imeni M.P. Drahomanova Seriia 18: Ekonomika i pravo [Scientific journal of NPU named after M.P. Drahomanov. Series 18: Economics and Law], 28, 65-72. [in Ukrainian].

4. Nepochatenko, O. O. (2014) Aktyvizatsiia investytsiinoi diialnosti iak sposib zmitsnennia finansovoi bezpeky ahrarnoho sektoru [Intensification of investment activity as a way to strengthen the financial security of the agricultural sector]. Ahrosvit [Ahrosvit], 2, 3-6. [in Ukrainian].

5. Bakhmatiuk, O. P. (2013). Infrastrukturni skladovi investytsiinoho rozvyyku ahrarnoho rehionu [Infrastructural components of investment development of the agricultural region]. Ahrosvit [Ahrosvit], 23, 16-21. [in Ukrainian].

6. Krysanov, D. F., Varchenko, O. M. (2017). Ahroprodovolchi lantsiuhy: kliuchovi problem stvorennia ta rozbudovy [Agro-food chains: key problems of creation and development]. Ekonomika i prohnozyvannia [Economics and forecasting], 1, 72-91. [in Ukrainian]. 